\title{
Morpho-Physiology and Anatomical Responses of Sorghum Seedlings as Affected by Salinity in Hydroponic Culture
}

\author{
M. N. Sarkar ${ }^{1}$, A. K. M. Z. Hossain ${ }^{1}$, S. N. Islam², S. Shahanaz ${ }^{3}$ and M. Z. Tareq ${ }^{4} *$ \\ ${ }^{I}$ Dept. of Crop Botany, Bangladesh Agricultural University, Mymensingh, Bangladesh \\ ${ }^{2}$ Bangladesh Jute Research Institute, Monirumpur, Jessore, Bangladesh \\ ${ }^{3}$ Department of Agricultural Extension, Monirumpur, Jessore, Bangladesh \\ ${ }^{4}$ Bangladesh Jute Research Institute, Jagir, Manikganj, Bangladesh \\ *Corresponding author and Email: zablulbarj@ gmail.com
}

Received: 06 April 2019

Accepted: 09 November 2019

\begin{abstract}
An experiment was conducted at the growth chamber of Department of Crop Botany in the Bangladesh Agricultural University, Mymensingh, Bangladesh during March 2018 to observe morpho-physiology and anatomical response of sorghum. Six genotypes were grown in hydroponics with a full nutrient solution $\left(\mathrm{NH}_{4} \mathrm{NO}_{3}-500 \mu \mathrm{M} ; \mathrm{Ca}\left(\mathrm{NO}_{3}\right)_{2}-500 \mu \mathrm{M} ; \mathrm{MgSO}_{4}-200 \mu \mathrm{M} ; \mathrm{KH}_{2} \mathrm{PO} 0_{4}-100 \mu \mathrm{M} ; \mathrm{FeCl}_{3}-2 \mu \mathrm{M}\right.$; $\left.\mathrm{H}_{2} \mathrm{BO}_{3}-11 \mu \mathrm{M} ; \mathrm{MnCl}_{2}-2 \mu \mathrm{M} ; \mathrm{ZnCl}_{2}-0.35 \mu \mathrm{M} ; \mathrm{CuCl}_{2}-0.2 \mu \mathrm{M} ;\left(\mathrm{NH}_{4}\right)_{6} \mathrm{Mo}_{7} \mathrm{O}_{4}-0.1 \mu \mathrm{M}\right)$ and $100 \mathrm{mM}$ salinity was imposed on 14 days seedlings. Data on morpho-physiological and anatomical parameters from seedlings were collected after 21 days and stress tolerant indexes of shoot and root were analyzed. Anatomical parameters like metaxylem and protoxylem thickness were also investigated. The results indicated that all the parameters viz. root length, shoot length, fresh and dry weight of shoot and root, stress tolerance index of root, and shoot, dry weight of shoot and root, relative chlorophyll content, photochemical efficiency $(\mathrm{Fv} / \mathrm{Fm})$, proline concentration, total root area, vascular cylinder area and root diameter were decreased with increasing salinity levels except leaf proline content. Genotypes BD 750 and BD 686 showed better performance considering tolerant indicators while the poor performance was exhibited by BD 747 and BD 753. Thus, based on overall observation BD 750 and BD 686 might be salt tolerant.
\end{abstract}

Keywords: Sorghum seedling, salinity, hydroponic culture, morpho-physiology and anatomy.

\section{Introduction}

Sorghum (Sorghum bicolor L.) known as great millet belongs to the family Poaceae is originated in Africa, and is now cultivated widely in tropical and subtropical regions (FAO 2015).

Globally, a total land area of 831 million hectares is salt affected. Salt accumulation is mainly related to a dry climate, salt rich parent materials of soil formation, insufficient drainage and saline groundwater or irrigation water (Almodares et al., 2008). Salts in soils are chlorides and sulfates of sodium, calcium, magnesium, and potassium. Among them sodium chloride has the highest negative effect on the plant growth and development. Soil salinity is an increasing problem in the world and main obstacle to agricultural productivity 
especially in areas where irrigation is necessary. Salinity is a common problem of Bangladesh. It is one of the major environmental stresses affecting plant growth and development results in severe agricultural losses (Tareq, 2009). These adverse physiological effects may be attributed to non-availability to water, reduction in photosynthesis through loss of turgidity impeded nutrient uptake causing deficiency and ion toxicity to plants. Salt stress may also impair synthesis of biochemical substances such as enzymes, sugars and protein (Singh et al., 2001). Crop plants growing under salt stress show reduction in dry matter accumulation and grain yield, which is invariably accompanied with pronounced changes in their ionic composition. During salinity stress decrease in $\mathrm{K}^{+}$and $\mathrm{Ca}^{2+}$ and accumulation of $\mathrm{Na}^{+}$and $\mathrm{Mg}^{2+}$ ions in both roots and shoots occurs in plant body. Salt tolerance in various crops has been associated with their ability to exclude sodium or chloride from shoot (Hossain et al., 2008). Selective uptake of non-toxic ions into the vascular saps and compartmentalization of toxic ions into the older plant parts and in to the vacuoles are considered to be important basis of tolerance of salinity (Flowers, 2004).

Sorghum is a crop of world-wide importance and is unique in its ability to produce under a wide array of harsh environmental condition (House, 1995). Among agricultural crops, it is naturally drought and salt-tolerant crop that can produce high biomass yields with low input. Also, it can thrive in places that do not support corn, sugarcane and other food crops. In terms of salinity tolerance degree it also be known as a moderately tolerant crop with the almost salinity tolerance of $6.8 \mathrm{dSm}^{-1}$ (Sultana, 2008). The study was designed to investigate the morphophysiology and anatomical responses of sorghum seedlings to salinity in hydroponic culture.

\section{Materials and Methods}

2.1 Plant growth, environment, and treatments The experiment was conducted at the growth chamber of Department of Crop Botany in
Bangladesh Agricultural University, Mymensingh, Bangladesh during March 2018. The experiment was conducted using six sorghum genotypes namely BD 686, BD 687, BD 693, BD 753, BD 750 and BD 747 to test their morpho-physiology and anatomical attributes against salinity $(0$ and $100 \mathrm{mM})$ at osmotic and ionic phases. The experiment was designed by using Completely Randomized Design (CRD) having three replications. Seeds were collected from Bangladesh Agricultural Research Institute (BARI), Gazipur.

The composition of the full strength nutrient solution was prepared according to Pitann et al. (2009). Seeds were surface sterilized with 5\% sodium hypochlorite for $30 \mathrm{~min}$ and washed three to four times with distilled water. Then the seeds were soaked overnight with water for imbibition. For salinization, $\mathrm{NaCl}$ was dissolved with nutrient solution to reach $100 \mathrm{mM}$ salinity. The salinity level was measured through EC using Sens ION EC-5 meter (Hach, Loveland, Colorado, US). At the age of 14 days of sorghum seedlings, saline treatments were imposed for next 8 days.

\subsection{Chlorophyll determination}

An index of the relative leaf chlorophyll content was measured by a chlorophyll meter (SPAD502, Konica Minolta, Japan). Readings were taken along the middle of the four leaves of one plant and the mean value was used for analysis. The measurements were made on ten plants from each treatment.

Chlorophyll fluorescence was measured with Pocket-PEA (Hansatech, Norfolk, UK). The maximal photo-chemical efficiency of PSII, $\mathrm{Fv} / \mathrm{Fm}=(\mathrm{Fm}-\mathrm{Fo}) / \mathrm{Fm}$ (Genty et al., 1989) was measured in dark-adapted (30 min) leaves at 8 th day. Well-developed $4^{\text {th }}$ leaves were selected for measurement.

\subsection{Proline determination}

The proline content of the supernatant was determined according to the method described by Zhang and Huang (2013). In brief, for the 
determination of proline content $0.50 \mathrm{~g}$ fresh leaves were collected from the 120-day old sorghum plants. The leaves were homogenized on a mortal-pastel with $4.0 \mathrm{~mL}$ of $3 \%$ sulfosalicylic acid and centrifuged at $11,500 \times \mathrm{g}$ for $15 \mathrm{~min}$. The supernatant was used for the proline estimation.

\subsection{Anatomical data collection}

The stressed plant roots were collected 14 days after salinization. For root anatomical studies, 1 $\mathrm{cm}$ root segments were collected after discarding $2 \mathrm{~cm}$ from root tip. Both well-developed $4^{\text {th }}$ leaf and root segments were kept in ethanol till transverse sections were made to observe the differences in anatomical structure.

Root and leaf anatomy of stressed and controlled plants were observed by light microscope (Axioscop; Carl Zeiss, Oberkochen, Germany). Here 10x and 40x of images were observed and captured. Images were processed for taking various anatomical parameters using the ZEISS ZEN digital imaging software for light microscopy. For root, metaxylem thickness and protoxylem thickness were measured from the same xylem strand. Vascular cylinder area and total root diameter were also measured. In each cell three positions were selected to take thickness values and then the average was calculated.

\subsection{Statistical analysis}

The collected data were subjected to statistical analysis following ANOVA technique. Differences among treatment means were adjusted by Duncan's Multiple Range Test with the help of a computer based statistical package program MSTAT-C (Gomez and Gomez, 1984).

\section{Results and Discussion}

\subsection{Effects of salinity on morphological characters}

3.1.1 Shoot length and its stress tolerance index (SLSTI)

The variation in shoot length among the studied genotypes was statistically significant at $\mathrm{P} \leq 0.01$ (Table 1). The highest shoot length was recorded in genotype BD $686(41.98 \mathrm{~cm})$ and BD $747 \mathrm{had}$ the shortest shoot length $(15.11 \mathrm{~cm})$.

For SLSI, the highest tolerance index was found in BD $686(97.16 \%)$ followed by BD 750 $(96.28 \%)$ and the lowest one was in BD 747 (87.10\%).

The effect of salinity on shoot length was significant (Table 2). The longest shoot length was recorded in control $(29.96 \mathrm{~cm})$ and the shortest was recorded in plants under $100 \mathrm{mM}$ $(26.08 \mathrm{~cm})$ salinity.

Table 1. Effects of genotypes on morphological characteristics at vegetative stage

\begin{tabular}{ccccccc}
\hline Genotypes & $\begin{array}{c}\text { Shoot } \\
\text { length } \\
(\mathrm{cm})\end{array}$ & $\begin{array}{c}\text { Shoot length } \\
\text { stress } \\
\text { tolerance } \\
\text { index }(\%)\end{array}$ & $\begin{array}{c}\text { Root } \\
\text { length } \\
(\mathrm{cm})\end{array}$ & $\begin{array}{c}\text { Root length } \\
\text { stress } \\
\text { tolerance } \\
\text { index }(\%)\end{array}$ & $\begin{array}{c}\text { Shoot fresh } \\
\text { weight } \\
(\mathrm{g} / \mathrm{hill})\end{array}$ & $\begin{array}{c}\text { Shoot fresh } \\
\text { weight stress } \\
\text { tolerance index } \\
(\%)\end{array}$ \\
\hline BD 686 & $41.98 \mathrm{a}$ & $97.16 \mathrm{a}$ & $21.90 \mathrm{c}$ & $92.41 \mathrm{c}$ & $4.27 \mathrm{~b}$ & $93.77 \mathrm{c}$ \\
BD 687 & $24.02 \mathrm{~d}$ & $91.28 \mathrm{c}$ & $19.65 \mathrm{~d}$ & $91.41 \mathrm{c}$ & $3.48 \mathrm{c}$ & $90.39 \mathrm{~d}$ \\
BD 693 & $31.21 \mathrm{c}$ & $93.70 \mathrm{~b}$ & $29.55 \mathrm{a}$ & $96.90 \mathrm{a}$ & $4.42 \mathrm{~b}$ & $94.48 \mathrm{~b}$ \\
BD 747 & $15.11 \mathrm{f}$ & $87.10 \mathrm{~d}$ & $14.40 \mathrm{e}$ & $87.28 \mathrm{~d}$ & $3.58 \mathrm{c}$ & $90.64 \mathrm{~d}$ \\
BD 750 & $38.81 \mathrm{~b}$ & $96.28 \mathrm{a}$ & $27.45 \mathrm{~b}$ & $95.31 \mathrm{~b}$ & $5.13 \mathrm{a}$ & $97.20 \mathrm{a}$ \\
BD 753 & $16.99 \mathrm{e}$ & $88.29 \mathrm{~d}$ & $12.73 \mathrm{f}$ & $86.63 \mathrm{~d}$ & $2.86 \mathrm{~d}$ & $87.81 \mathrm{e}$ \\
\hline LSD & 0.793 & 1.69 & 0.733 & 1.38 & 0.169 & 0.736 \\
\hline
\end{tabular}

In a column, within either genotype or salinity, figures having similar letter(s) do not differ significantly at $5 \%$ level of probability. 
Table 2. Effects of salinity level on morphological characteristics at vegetative stage

\begin{tabular}{|c|c|c|c|c|c|c|}
\hline $\begin{array}{l}\text { Salinity } \\
\text { level }\end{array}$ & $\begin{array}{l}\text { Shoot } \\
\text { length } \\
(\mathrm{cm})\end{array}$ & $\begin{array}{l}\text { Shoot length } \\
\text { stress } \\
\text { tolerance } \\
\text { index }(\%)\end{array}$ & $\begin{array}{l}\text { Root } \\
\text { length } \\
(\mathrm{cm})\end{array}$ & $\begin{array}{l}\text { Root length } \\
\text { stress } \\
\text { tolerance } \\
\text { index }(\%)\end{array}$ & $\begin{array}{l}\text { Shoot } \\
\text { fresh } \\
\text { weight } \\
\text { (g/hill) }\end{array}$ & $\begin{array}{l}\text { Shoot fresh } \\
\text { weight stress } \\
\text { tolerance } \\
\text { index }(\%)\end{array}$ \\
\hline $0 \mathrm{mM}$ & $29.96 a$ & $100.00 \mathrm{a}$ & $22.62 \mathrm{a}$ & $100.00 \mathrm{a}$ & $4.26 \mathrm{a}$ & $100.00 \mathrm{a}$ \\
\hline $100 \mathrm{mM}$ & $26.08 b$ & $84.60 \mathrm{~b}$ & $19.28 b$ & $83.31 \mathrm{~b}$ & $3.65 \mathrm{~b}$ & $84.76 b$ \\
\hline LSD & 0.458 & 0.975 & 0.423 & 0.796 & 0.097 & 0.425 \\
\hline
\end{tabular}

In a column, within either genotype or salinity, figures having similar letter(s) do not differ significantly at $5 \%$ level of probability.

Table 3. Combined effects of genotypes and salinity level on morphological characteristics at vegetative stage

\begin{tabular}{ccccccc}
\hline $\begin{array}{c}\text { Interaction } \\
\text { of genotype } \\
\text { to salinity }\end{array}$ & $\begin{array}{c}\text { Shoot } \\
\text { length } \\
(\mathrm{cm})\end{array}$ & $\begin{array}{c}\text { Shoot length } \\
\text { stress } \\
\text { tolerance } \\
\text { index }(\%)\end{array}$ & $\begin{array}{c}\text { Root } \\
\text { length } \\
(\mathrm{cm})\end{array}$ & $\begin{array}{c}\text { Root length } \\
\text { stress } \\
\text { tolerance } \\
\text { index }(\%)\end{array}$ & $\begin{array}{c}\text { Shoot } \\
\text { fresh } \\
\text { weight } \\
(\mathrm{g} / \mathrm{hill})\end{array}$ & $\begin{array}{c}\text { Shoot fresh } \\
\text { weight stress } \\
\text { tolerance } \\
\text { index }(\%)\end{array}$ \\
\hline $\mathrm{T}_{1} \mathrm{~V}_{1}$ & $43.23 \mathrm{a}$ & $100.0 \mathrm{a}$ & $23.70 \mathrm{~d}$ & $100.0 \mathrm{a}$ & $4.55 \mathrm{c}$ & $100.00 \mathrm{a}$ \\
$\mathrm{T}_{1} \mathrm{~V}_{2}$ & $26.31 \mathrm{f}$ & $100.0 \mathrm{a}$ & $21.50 \mathrm{e}$ & $100.0 \mathrm{a}$ & $3.85 \mathrm{e}$ & $100.00 \mathrm{a}$ \\
$\mathrm{T}_{1} \mathrm{~V}_{3}$ & $33.31 \mathrm{~d}$ & $100.0 \mathrm{a}$ & $30.50 \mathrm{a}$ & $100.0 \mathrm{a}$ & $4.68 \mathrm{c}$ & $100.00 \mathrm{a}$ \\
$\mathrm{T}_{1} \mathrm{~V}_{4}$ & $17.35 \mathrm{i}$ & $100.0 \mathrm{a}$ & $16.50 \mathrm{~h}$ & $100.0 \mathrm{a}$ & $3.95 \mathrm{de}$ & $100.00 \mathrm{a}$ \\
$\mathrm{T}_{1} \mathrm{~V}_{5}$ & $40.31 \mathrm{~b}$ & $100.0 \mathrm{a}$ & $28.80 \mathrm{~b}$ & $100.0 \mathrm{a}$ & $5.28 \mathrm{a}$ & $100.00 \mathrm{a}$ \\
$\mathrm{T}_{1} \mathrm{~V}_{6}$ & $19.25 \mathrm{~h}$ & $100.0 \mathrm{a}$ & $14.70 \mathrm{i}$ & $100.0 \mathrm{a}$ & $3.25 \mathrm{f}$ & $100.00 \mathrm{a}$ \\
$\mathrm{T}_{2} \mathrm{~V}_{1}$ & $40.72 \mathrm{~b}$ & $94.33 \mathrm{~b}$ & $20.10 \mathrm{f}$ & $84.82 \mathrm{~d}$ & $3.98 \mathrm{de}$ & $87.53 \mathrm{~d}$ \\
$\mathrm{~T}_{2} \mathrm{~V}_{2}$ & $21.72 \mathrm{~g}$ & $82.55 \mathrm{~d}$ & $17.80 \mathrm{~g}$ & $82.81 \mathrm{e}$ & $3.11 \mathrm{f}$ & $80.79 \mathrm{e}$ \\
$\mathrm{T}_{2} \mathrm{~V}_{3}$ & $29.11 \mathrm{e}$ & $87.40 \mathrm{c}$ & $28.60 \mathrm{~b}$ & $93.81 \mathrm{~b}$ & $4.16 \mathrm{~d}$ & $88.96 \mathrm{c}$ \\
$\mathrm{T}_{2} \mathrm{~V}_{4}$ & $12.87 \mathrm{k}$ & $74.20 \mathrm{e}$ & $12.30 \mathrm{j}$ & $74.56 \mathrm{f}$ & $3.21 \mathrm{f}$ & $81.28 \mathrm{e}$ \\
$\mathrm{T}_{2} \mathrm{~V}_{5}$ & $37.31 \mathrm{c}$ & $92.56 \mathrm{~b}$ & $26.10 \mathrm{c}$ & $90.63 \mathrm{c}$ & $4.98 \mathrm{~b}$ & $94.40 \mathrm{~b}$ \\
$\mathrm{~T}_{2} \mathrm{~V}_{6}$ & $14.74 \mathrm{j}$ & $76.57 \mathrm{e}$ & $10.77 \mathrm{k}$ & $73.26 \mathrm{f}$ & $2.46 \mathrm{~g}$ & $75.62 \mathrm{f}$ \\
$\mathrm{LSD}$ & 1.12 & 2.39 & 1.04 & 1.95 & 0.238 & 1.042 \\
\hline
\end{tabular}

In a column, figures having similar letter(s) do not differ significantly at 5\% level of probability. Here, "V" represents the Variety or Genotypes, $\mathrm{V}_{1}=\mathrm{BD} 686 ; \mathrm{V}_{2}=\mathrm{BD} 687 ; \mathrm{V}_{3}=\mathrm{BD} 693 ; \mathrm{V}_{4}=\mathrm{BD}$ 747; $\mathrm{V}_{5}=\mathrm{BD} 750 ; \mathrm{V}_{6}=\mathrm{BD} 753 ; \mathrm{T}_{1}=0 \mathrm{mM}$ (control); $\mathrm{T}_{2}=100 \mathrm{mM} \mathrm{NaCl}$ concentration.

The interaction effect of salinity levels to genotypes at vegetative stage had a significant effect on shoot length and SLSI (Table 3). Results revealed that shoot length was less affected in $\mathrm{T}_{1} \mathrm{~V}_{1}(43.23 \mathrm{~cm})$. It indicates that the genotype had salinity tolerance in growth and development than the others. In contrast, shoot length was affected severely in all the genotypes at $100 \mathrm{mM}$ and shortest shoot length was recorded in $\mathrm{T}_{2} \mathrm{~V}_{4}(12.87 \mathrm{~cm})$. Similar results were reported by Szalai and Janda (2009); Farooq et al., (2015); Hamid et al. (2008).

Again SLSI was significantly reduced due to salinity stress. However, it varied in different sorghum cultivars under different levels of salinity. In each case, SLSI was 100 in control . But the maximum SLSI value was recorded in $\mathrm{T}_{2} \mathrm{~V}_{1}(94.33 \%)$ and lowest SLSI $(74.20 \%)$ was found in $\mathrm{T}_{2} \mathrm{~V}_{4}$ followed by $\mathrm{T}_{2} \mathrm{~V}_{6}(76.57 \%$ ) (Table 
3). Similar results were reported by Szalai and Janda (2009); Farooq et al. (2015); Hamid et al., (2008).

\subsubsection{Root length and its stress tolerance index (RLSI)}

The variation of root length among the genotypes was significant at $\mathrm{P} \leq 0.01$ (Table 1). The highest shoot length was $29.55 \mathrm{~cm}$ in BD 693 () and the lowest one was in BD 747 (12.73 $\mathrm{cm})$. For RLSI, the highest tolerance index was in BD $693(96.90 \%)$ and the lowest one was in BD 753 (86.63\%)

The effect of salinity on root length was found significant (Table 2). The longest root length was recorded in control $(22.62 \mathrm{~cm})$ and the shortest one was recorded in $100 \mathrm{mM}(19.28 \mathrm{~cm})$. For SLSI no reduction occurred in control condition while $100 \mathrm{mM}$ exhibited the highest reduction $(83.31 \%)$.

The interaction between salinity levels and genotypes at vegetative stage had a significant effect on root length and RLSI (Table 3). Results revealed that root length was less affected in $\mathrm{T}_{1} \mathrm{~V}_{3}(30.5 \mathrm{~cm})$. In contrast, root length was affected severely in all the genotypes at $100 \mathrm{mM}$ and shortest root length was recorded in $\mathrm{T}_{2} \mathrm{~V}_{6}$ $(10.77 \mathrm{~cm})$. Again RLSI was significantly reduced due to the effect of salinity. The maximum RLSI value was recorded in $\mathrm{T}_{2} \mathrm{~V}_{3}$ (93.81\%) and $\mathrm{T}_{2} \mathrm{~V}_{6}$ had the lowest RLSI (73.26\%) followed by $\mathrm{T}_{2} \mathrm{~V}_{4}(74.56 \%)$. Similar results were reported by Szalai and Janda (2009); Farooq et al.( 2015); Hamid et al.( 2008).

\subsubsection{Shoot fresh weight and its stress tolerance index (SFSTI)}

The shoot fresh weight varied significantly among the genotypes (Table 1). The highest shoot fresh weight was recorded in BD 750 (5.13 $\mathrm{g} / \mathrm{hill})$ followed by BD 686 (4.27 g/hill) and BD 693 (4.42 g/hill). The lowest shoot fresh weight was in BD 753 (2.86 g/hill). For SFSTI, the highest tolerance index was obtained in BD 750
$(97.2 \%)$ and the lowest one was in BD 747 $(87.81 \%)$.

The effect of salinity on shoot fresh weight was found statistically significant (Table 2). The highest shoot fresh weight was recorded in control (4.26 g/hill) and the lowest was recorded in $100 \mathrm{mM}$ (3.65 g/hill). In case of SFSTI, no reduction occurred in control condition while $100 \mathrm{mM}$ exhibited the highest reduction $(84.76 \%)$.

The interaction of salinity levels to genotypes at vegetative stage had a significant effect on shoot fresh weight and SFSTI (Table 3). The shoot fresh weight was less affected in $\mathrm{T}_{1} \mathrm{~V}_{5}(5.28$ $\mathrm{g} / \mathrm{hill}$ ). In contrast, shoot fresh weight was severely affected in all the genotypes at $100 \mathrm{mM}$ and shortest shoot fresh weight was recorded in $\mathrm{T}_{2} \mathrm{~V}_{6}(2.46 \mathrm{~g} / \mathrm{hill})$.

Similarly salinity affected SFSTI significantly which varied in sorghum cultivars. Considering SFSTI 100 in control the SFSTI value was in $\mathrm{T}_{2} \mathrm{~V}_{5}(94.40 \%)$ and in $\mathrm{T}_{2} \mathrm{~V}_{6}(75.62 \%)$ (Table 3). Similar results were reported by Szalai and Janda, 2009; Farooq et al., 2015; Hamid et al., 2008.

\subsubsection{Root fresh weight and its stress tolerance index (RFSTI)}

The variation in root fresh weight among the six genotypes was significant at $\mathrm{P} \leq 0.01$ (Table 4). The highest root fresh weight was in BD 750 (1.26 g/hill) and the lowest one was in BD 747 (0.51 g/hill). For RFSTI, the highest tolerance index was in BD $686(97.97 \%)$ and the lowest one was in BD 747 (84.14\%).

The salinity affected root fresh weight significantly (Table 5). The root fresh weight was $0.91 \mathrm{~g} / \mathrm{hill}$ in control (Table 5) which reduced to $0.76 \mathrm{~g} /$ hill in $100 \mathrm{mM}$. (Table 5). Similarly RFSTI reduced to $80.80 \%$ at $100 \mathrm{mM}$ salinity. 
Table 4. Effects of genotypes on morphological characteristics at vegetative stage

\begin{tabular}{ccccccc}
\hline Genotypes & $\begin{array}{c}\text { Root fresh } \\
\text { weight } \\
(\mathrm{g} / \mathrm{hill})\end{array}$ & $\begin{array}{c}\text { Root fresh } \\
\text { weight stress } \\
\text { tolerance } \\
\text { index }(\%)\end{array}$ & $\begin{array}{c}\text { Shoot dry } \\
\text { weight } \\
(\mathrm{g} / \mathrm{hill})\end{array}$ & $\begin{array}{c}\text { Shoot dry } \\
\text { weight stress } \\
\text { tolerance } \\
\text { index }(\%)\end{array}$ & $\begin{array}{c}\text { Root } \\
\text { dry } \\
\text { weight } \\
(\mathrm{g} / \mathrm{hill})\end{array}$ & $\begin{array}{c}\text { Root dry } \\
\text { weight stress } \\
\text { tolerance } \\
\text { index }(\%)\end{array}$ \\
\hline BD 686 & $1.09 \mathrm{~b}$ & $97.97 \mathrm{a}$ & $1.51 \mathrm{ab}$ & $93.03 \mathrm{~b}$ & $0.39 \mathrm{ab}$ & $93.94 \mathrm{~b}$ \\
BD 687 & $0.77 \mathrm{c}$ & $88.95 \mathrm{~d}$ & $1.21 \mathrm{ab}$ & $88.11 \mathrm{~d}$ & $0.31 \mathrm{~b}$ & $89.70 \mathrm{e}$ \\
BD 693 & $0.82 \mathrm{c}$ & $89.56 \mathrm{c}$ & $1.27 \mathrm{ab}$ & $89.23 \mathrm{c}$ & $0.33 \mathrm{~b}$ & $90.28 \mathrm{~d}$ \\
BD 747 & $0.51 \mathrm{e}$ & $84.14 \mathrm{f}$ & $0.92 \mathrm{~b}$ & $84.20 \mathrm{f}$ & $0.23 \mathrm{c}$ & $85.61 \mathrm{f}$ \\
BD 750 & $1.26 \mathrm{a}$ & $96.19 \mathrm{~b}$ & $1.74 \mathrm{a}$ & $97.39 \mathrm{a}$ & $0.45 \mathrm{a}$ & $97.89 \mathrm{a}$ \\
BD 753 & $0.57 \mathrm{~d}$ & $85.59 \mathrm{e}$ & $0.97 \mathrm{~b}$ & $84.90 \mathrm{e}$ & $0.25 \mathrm{c}$ & $86.13 \mathrm{e}$ \\
\hline LSD & 0.053 & 0.689 & 0.100 & 6.105 & 0.038 & 1.857 \\
\hline
\end{tabular}

Table 5. Effects of salinity on morphological characteristics at vegetative stage

\begin{tabular}{|c|c|c|c|c|c|c|}
\hline $\begin{array}{c}\text { Salinity } \\
\text { level }\end{array}$ & $\begin{array}{c}\text { Root } \\
\text { fresh } \\
\text { weight } \\
\text { (g/hill) }\end{array}$ & $\begin{array}{l}\text { Root fresh } \\
\text { weight stress } \\
\text { tolerance } \\
\text { index }(\%)\end{array}$ & $\begin{array}{l}\text { Shoot dry } \\
\text { weight } \\
\text { (g/hill) }\end{array}$ & $\begin{array}{c}\text { Shoot dry } \\
\text { weight stress } \\
\text { tolerance index } \\
(\%)\end{array}$ & $\begin{array}{l}\text { Root dry } \\
\text { weight } \\
\text { (g/hill) }\end{array}$ & $\begin{array}{c}\text { Root dry } \\
\text { weight stress } \\
\text { tolerance } \\
\text { index }(\%)\end{array}$ \\
\hline $0 \mathrm{mM}$ & $0.91 \mathrm{a}$ & $100.00 \mathrm{a}$ & $1.40 \mathrm{a}$ & $100.00 \mathrm{a}$ & $0.35 a$ & $100.00 \mathrm{a}$ \\
\hline $100 \mathrm{mM}$ & $0.76 b$ & $80.80 b$ & $1.13 b$ & $78.95 b$ & $0.29 b$ & $81.18 b$ \\
\hline LSD & 0.031 & 0.398 & 0.058 & 3.525 & 0.022 & 1.072 \\
\hline
\end{tabular}

Table 6. Combined effects of genotypes to salinity level on morphological characteristics at vegetative

\begin{tabular}{lcccccc}
\hline $\begin{array}{c}\text { Interaction } \\
\text { of } \\
\text { genotype } \\
\text { to salinity }\end{array}$ & $\begin{array}{c}\text { Root } \\
\text { fresh } \\
\text { weight } \\
\text { (g/hill) }\end{array}$ & $\begin{array}{c}\text { Root fresh } \\
\text { weight stress } \\
\text { tolerance } \\
\text { index }(\%)\end{array}$ & $\begin{array}{c}\text { Shoot dry } \\
\text { weight } \\
(\mathrm{g} / \mathrm{hill})\end{array}$ & $\begin{array}{c}\text { Shoot dry } \\
\text { weight stress } \\
\text { tolerance } \\
\text { index }(\%)\end{array}$ & $\begin{array}{c}\text { Root dry } \\
\text { weight } \\
(\mathrm{g} / \mathrm{hill})\end{array}$ & $\begin{array}{c}\text { Root dry } \\
\text { weight stress } \\
\text { tolerance } \\
\text { index }(\%)\end{array}$ \\
\hline $\mathrm{T}_{1} \mathrm{~V}_{1}$ & $1.11 \mathrm{c}$ & $100.00 \mathrm{a}$ & $1.62 \mathrm{c}$ & $100.00 \mathrm{a}$ & 0.41 & $100.00 \mathrm{a}$ \\
$\mathrm{T}_{1} \mathrm{~V}_{2}$ & $0.86 \mathrm{~d}$ & $100.00 \mathrm{a}$ & $1.37 \mathrm{~d}$ & $100.00 \mathrm{a}$ & 0.34 & $100.00 \mathrm{a}$ \\
$\mathrm{T}_{1} \mathrm{~V}_{3}$ & $0.91 \mathrm{~d}$ & $100.00 \mathrm{a}$ & $1.42 \mathrm{~d}$ & $100.00 \mathrm{a}$ & 0.36 & $100.00 \mathrm{a}$ \\
$\mathrm{T}_{1} \mathrm{~V}_{4}$ & $0.60 \mathrm{f}$ & $100.00 \mathrm{a}$ & $1.09 \mathrm{ef}$ & $100.00 \mathrm{a}$ & 0.27 & $100.00 \mathrm{a}$ \\
$\mathrm{T}_{1} \mathrm{~V}_{5}$ & $1.31 \mathrm{a}$ & $100.00 \mathrm{a}$ & $1.79 \mathrm{a}$ & $100.00 \mathrm{a}$ & 0.46 & $100.00 \mathrm{a}$ \\
$\mathrm{T}_{1} \mathrm{~V}_{6}$ & $0.66 \mathrm{ef}$ & $100.00 \mathrm{a}$ & $1.14 \mathrm{e}$ & $100.00 \mathrm{a}$ & 0.29 & $100.00 \mathrm{a}$ \\
$\mathrm{T}_{2} \mathrm{~V}_{1}$ & $1.07 \mathrm{c}$ & $95.94 \mathrm{a}$ & $1.39 \mathrm{~d}$ & $86.06 \mathrm{c}$ & 0.36 & $87.88 \mathrm{c}$ \\
$\mathrm{T}_{2} \mathrm{~V}_{2}$ & $0.67 \mathrm{ef}$ & $77.90 \mathrm{~b}$ & $1.04 \mathrm{f}$ & $76.22 \mathrm{~d}$ & 0.27 & $79.40 \mathrm{~d}$ \\
$\mathrm{~T}_{2} \mathrm{~V}_{3}$ & $0.72 \mathrm{e}$ & $79.12 \mathrm{~b}$ & $1.11 \mathrm{e}$ & $78.47 \mathrm{~d}$ & 0.29 & $80.56 \mathrm{~d}$ \\
$\mathrm{~T}_{2} \mathrm{~V}_{4}$ & $0.41 \mathrm{~g}$ & $68.28 \mathrm{c}$ & $0.74 \mathrm{~g}$ & $68.40 \mathrm{e}$ & 0.19 & $71.22 \mathrm{e}$ \\
$\mathrm{T}_{2} \mathrm{~V}_{5}$ & $1.21 \mathrm{~b}$ & $92.38 \mathrm{a}$ & $1.69 \mathrm{~b}$ & $94.78 \mathrm{~b}$ & 0.44 & $95.78 \mathrm{~b}$ \\
$\mathrm{~T}_{2} \mathrm{~V}_{6}$ & $0.47 \mathrm{~g}$ & $71.18 \mathrm{bc}$ & $0.79 \mathrm{~g}$ & $69.79 \mathrm{e}$ & 0.21 & $72.26 \mathrm{e}$ \\
\hline $\mathrm{LSD}$ & 0.075 & 0.974 & 0.141 & 8.634 & 0.053 & 2.626 \\
\hline
\end{tabular}

In a column figures having similar letter(s) do not differ significantly at $5 \%$ level of probability. $\mathrm{V}_{1}=$ BD 686; $\mathrm{V}_{2}=\mathrm{BD} 687 ; \mathrm{V}_{3}=\mathrm{BD} 693 ; \mathrm{V}_{4}=\mathrm{BD} 747 ; \mathrm{V}_{5}=\mathrm{BD} 750 ; \mathrm{V}_{6}=\mathrm{BD} 753 . \mathrm{T}_{1}=0 \mathrm{mM}$ (control); $\mathrm{T}_{2}=100 \mathrm{mM} \mathrm{NaCl}$. 
The interaction between salinity levels and genotypes at vegetative stage had significant effects on root fresh weight and RFSTI (Table $6)$. Results revealed that root fresh weight was less affected in $\mathrm{T}_{1} \mathrm{~V}_{5}(1.31 \mathrm{~g} / \mathrm{hill})$. In contrast, root fresh weight was severely affected in all the genotypes at $100 \mathrm{mM}$ and shortest root fresh weight was recorded in $\mathrm{T}_{2} \mathrm{~V}_{4} \quad(0.41 \mathrm{~g} / \mathrm{hill})$ followed by $\mathrm{T}_{2} \mathrm{~V}_{6}(0.47 \mathrm{~g} / \mathrm{hill})$. In each case, RFSTI was 100 in control condition. But the maximum RFSTI value was recorded in $\mathrm{T}_{2} \mathrm{~V}_{1}$ (95.94\%) followed by $\mathrm{T}_{2} \mathrm{~V}_{5}(92.38 \%)$ and $\mathrm{T}_{2} \mathrm{~V}_{4}$ had lowest RFSTI value (75.62\%). These results are agreement with Dafalla et al., (2014); Kafi et al., (2013); Farooq et al., (2015); Queiroz et al., (2012).

\subsubsection{Shoot dry weight and its stress tolerance index (SDSTI)}

The variation in shoot dry weight among the studied genotypes was statistically significant at $\mathrm{P} \leq 0.01$ (Table 4). The highest shoot dry weight was recorded in BD 750 (1.74 g/hill). BD 747 had the lowest shoot dry weight $(0.92 \mathrm{~g} / \mathrm{hill})$ followed by BD 753 (0.97 g/hill). Again in case of SDSTI, the highest tolerance index was shown by BD $750(97.39 \%)$ and the lowest tolerance was shown by BD $747(84.20 \%)$. The effect of salinity on shoot dry weight was found statistically significant (Table 5). The highest shoot dry weight was recorded in control (1.4 $\mathrm{g} / \mathrm{hill}$ ) and the lowest was recorded in $100 \mathrm{mM}$ (1.13 g/hill). In case of SFSTI, no reduction occurred in control while $100 \mathrm{mM}$ exhibited the highest reduction $(78.95 \%)$.

The interaction between salinity levels and genotypes at vegetative stage had a significant effect on shoot dry weight and SDSTI (Table 6). Results revealed that shoot dry weight was less affected in $\mathrm{T}_{1} \mathrm{~V}_{5}(1.79 \mathrm{~g} / \mathrm{hill})$. It indicates that this genotype had salinity tolerance in growth and development than the others. In contrast, shoot dry weight was severely affected in all the genotypes at $100 \mathrm{mM}$ and smallest shoot dry weight was recorded in $\mathrm{T}_{2} \mathrm{~V}_{4}$ $(0.74 \mathrm{~g} / \mathrm{hill})$ followed by $\mathrm{T}_{2} \mathrm{~V}_{6}(0.79 \mathrm{~g} / \mathrm{hill})$. Again SDSTI was significantly reduced by the application of salt. In each case, SDSTI was 100 in control condition. But the maximum SDSTI value was recorded in $\mathrm{T}_{2} \mathrm{~V}_{5}(94.78 \%)$ and $\mathrm{T}_{2} \mathrm{~V}_{4}$ had lowest SDSTI (68.4\%) followed by $\mathrm{T}_{2} \mathrm{~V}_{6}(69.79 \%)$.

\subsubsection{Root dry weight and its stress tolerance index (RDSTI)}

The variation in root dry weight among the six genotypes was statistically significant at $\mathrm{P} \leq 0.01$ (Table 4). The highest root dry weight was recorded in BD 750 (0.45 g/hill). BD 747 had the lowest root dry weight $(0.23 \mathrm{~g} / \mathrm{hill})$ followed by BD 753 (0.25 g/hill). Again in case of RDSTI, the highest tolerance index was shown by BD $750(97.89 \%)$ and the lowest tolerance was shown by BD 747 (85.61\%).

The effect of salinity on root dry weight was found statistically significant (Table 5). The highest root dry weight was recorded in control $(0.35 \mathrm{~g} / \mathrm{hill})$ and the lowest was recorded in $100 \mathrm{mM}(0.29 \mathrm{~g} / \mathrm{hill})$. In case of RDSTI, no reduction occurred in control condition while $100 \mathrm{mM}$ exhibited the highest reduction $(81.18 \%)$.

There was no significant interaction between salinity levels and genotypes in terms of root dry weight. But RDSTI was significantly reduced by the application of salinity (Table 6). In each case, RFSTI was 100 in control condition. But the maximum RDSTI value was recorded in $\mathrm{T}_{2} \mathrm{~V}_{5}(95.78 \%)$ and $\mathrm{T}_{2} \mathrm{~V}_{4}$ had lowest RFSTI (71.22\%) followed by $\mathrm{T}_{2} \mathrm{~V}_{6}$ $(72.26 \%)$. These results are agreement with Dafalla et al., (2014); Kafi et al., (2013); Farooq et al., (2015); Queiroz et al., (2012).

\subsection{Effects of salinity on physiological characters}

3.2.1 Relative chlorophyll content (SPAD index)

The relative chlorophyll content significantly differed among six genotypes at $\mathrm{P} \leq 0.01$. BD 750 (35.92) has the highest relative chlorophyll content than the others followed by BD 686 (34.82) while the lowest content was observed in 
BD 687 (27.14; Table 7). Relative chlorophyll content was significantly affected due to salinity at $\mathrm{P} \leq 0.01$. The highest content was in control condition (33.82) and the lowest content was observed at $100 \mathrm{mM}$ salinity level (28.94; Table 8).

The interaction between salinity levels and genotypes had a significant effect on relative chlorophyll content (SPAD) (Table 9). Results showed that SPAD index value was high in $\mathrm{T}_{1} \mathrm{~V}_{5}$ (36.57) followed by $T_{1} V_{1}$ (36.07) in controlled condition. In contrast, SPAD index was severely affected in all the genotypes at $100 \mathrm{mM}$ and smallest SPAD index was recorded in $T_{2} V_{2}$ (23.21). Reduced relative chlorophyll content at salt stress may be due to the immediate effect of salinity on plant leaf while at the later stage plant might be regaining its tolerance. A similar result was found by Niu et al., (2012).

\subsubsection{Maximum photochemical efficiency of PSII (Fv/Fm)}

The variation in $\mathrm{Fv} / \mathrm{Fm}$ value among the six genotypes was statistically significant at $\mathrm{P} \leq 0.01$ (Table 7). The highest Fv/Fm value was recorded in BD $693(0.775)$. BD 747 had the lowest
Fv/Fm value (0.720). FV/Fm value was significantly affected due to salinity at $\mathrm{P} \leq 0.01$ (Table 8). The maximum value was recorded in control condition (0.769). In contrast minimum was in $100 \mathrm{mM}$ (0.730).Maximum photochemical efficiency of sorghum decreased with increasing salinity level but there is no interaction effect of genotypes and salinity on $\mathrm{Fv} / \mathrm{Fm}$ value. These results are in agreement with the results of the previous researches that salinity may affect maximum photochemical efficiency of PS II (Fm/Fv) (Niu et al., 2012; Netondo et al., 2004b; Akram et al.,2011).

\subsubsection{Proline content in sorghum leaf}

The variation in leaf proline among the studied genotypes was statistically significant (Table 7). The highest leaf proline content was recorded in BD 750 (3.47 mg/100g FW). In contrast, BD 747 and BD 693 had the lowest leaf proline (1.80 $\mathrm{mg} / 100 \mathrm{~g} \mathrm{FW}$ ). The effect of salinity on leaf proline was found statistically significant (Table 8). Result revealed that the highest leaf proline content was recorded in saline condition at 100 $\mathrm{mM}(3.17 \mathrm{mg} / 100 \mathrm{~g} \mathrm{FW})$ and the lowest was recorded in control condition $(1.28 \mathrm{mg} / 100 \mathrm{~g} \mathrm{FW})$

Table 7. Effects of genotypes on physiological characteristics at vegetative stage

\begin{tabular}{cccc}
\hline Genotypes & SPAD & Fv/Fm & Proline $(\mathrm{mg} / 100 \mathrm{~g}$ FW) \\
\hline BD 686 & $34.82 \mathrm{~b}$ & $0.763 \mathrm{ab}$ & $2.34 \mathrm{~b}$ \\
BD 687 & $27.14 \mathrm{f}$ & $0.743 \mathrm{bc}$ & $1.98 \mathrm{c}$ \\
BD 693 & $31.59 \mathrm{c}$ & $0.775 \mathrm{a}$ & $1.80 \mathrm{c}$ \\
BD 747 & $27.97 \mathrm{e}$ & $0.720 \mathrm{~d}$ & $1.80 \mathrm{c}$ \\
BD 750 & $35.92 \mathrm{a}$ & $0.760 \mathrm{ab}$ & $3.47 \mathrm{a}$ \\
BD 753 & $30.85 \mathrm{~d}$ & $0.735 \mathrm{~cd}$ & $1.93 \mathrm{c}$ \\
\hline LSD & 0.623 & 0.022 & 0.053 \\
\hline
\end{tabular}

Table 8. Effects of salinity level on physiological characteristics at vegetative stage

\begin{tabular}{cccc}
\hline Salinity level & SPAD & Fv/Fm & Proline $(\mathrm{mg} / 100 \mathrm{~g}$ FW $)$ \\
\hline $0 \mathrm{mM}$ & $33.82 \mathrm{a}$ & $0.769 \mathrm{a}$ & $1.28 \mathrm{~b}$ \\
$100 \mathrm{mM}$ & $28.94 \mathrm{~b}$ & $0.730 \mathrm{~b}$ & $3.17 \mathrm{a}$ \\
\hline LSD & 0.359 & 0.013 & 0.031 \\
\hline
\end{tabular}

In a column figures having similar letter(s) do not differ significantly at $5 \%$ level of probability. 
Table 9. Combined effects of genotypes to salinity level on physiological and biochemical characteristics at vegetative stage

\begin{tabular}{cccc}
\hline $\begin{array}{c}\text { Interaction of genotype } \\
\text { to salinity }\end{array}$ & $\mathrm{SPAD}$ & $\mathrm{Fv} / \mathrm{Fm}$ & Proline $(\mathrm{mg} / 100 \mathrm{~g} \mathrm{FW})$ \\
\hline $\mathrm{T}_{1} \mathrm{~V}_{1}$ & $36.07 \mathrm{a}$ & 0.780 & $1.05 \mathrm{~g}$ \\
$\mathrm{~T}_{1} \mathrm{~V}_{2}$ & $31.07 \mathrm{~d}$ & 0.760 & $1.47 \mathrm{efg}$ \\
$\mathrm{T}_{1} \mathrm{~V}_{3}$ & $34.07 \mathrm{c}$ & 0.807 & $0.80 \mathrm{~g}$ \\
$\mathrm{~T}_{1} \mathrm{~V}_{4}$ & $31.57 \mathrm{~d}$ & 0.737 & $1.50 \mathrm{efg}$ \\
$\mathrm{T}_{1} \mathrm{~V}_{5}$ & $36.57 \mathrm{a}$ & 0.780 & $1.23 \mathrm{fg}$ \\
$\mathrm{T}_{1} \mathrm{~V}_{6}$ & $33.57 \mathrm{c}$ & 0.750 & $1.60 \mathrm{~d}-\mathrm{g}$ \\
$\mathrm{T}_{2} \mathrm{~V}_{1}$ & $33.57 \mathrm{c}$ & 0.747 & $3.63 \mathrm{~b}$ \\
$\mathrm{~T}_{2} \mathrm{~V}_{2}$ & $23.21 \mathrm{~h}$ & 0.727 & $2.50 \mathrm{~cd}$ \\
$\mathrm{~T}_{2} \mathrm{~V}_{3}$ & $29.11 \mathrm{e}$ & 0.743 & $2.80 \mathrm{bc}$ \\
$\mathrm{T}_{2} \mathrm{~V}_{4}$ & $24.37 \mathrm{~g}$ & 0.703 & $2.10 \mathrm{c}-\mathrm{f}$ \\
$\mathrm{T}_{2} \mathrm{~V}_{5}$ & $35.27 \mathrm{~b}$ & 0.740 & $5.70 \mathrm{a}$ \\
$\mathrm{T}_{2} \mathrm{~V}_{6}$ & $28.12 \mathrm{f}$ & 0.720 & $2.27 \mathrm{cde}$ \\
\hline $\mathrm{LSD}$ & 0.880 & 0.031 & 0.075 \\
\hline
\end{tabular}

In a column figures having similar letter(s) do not differ significantly at $5 \%$ level of probability. $\mathrm{V}_{1}=$ BD 686; $\mathrm{V}_{2}=\mathrm{BD} 687 ; \mathrm{V}_{3}=\mathrm{BD} 693 ; \mathrm{V}_{4}=\mathrm{BD} 747 ; \mathrm{V}_{5}=\mathrm{BD} 750 ; \mathrm{V}_{6}=\mathrm{BD}$ 753. $\mathrm{T}_{1}=0 \mathrm{mM}$ (control); $\mathrm{T}_{2}=100 \mathrm{mM} \mathrm{NaCl}$.

Table 10. Effects of genotypes on anatomical characteristics at vegetative stage

\begin{tabular}{cccccc}
\hline Genotypes & $\begin{array}{c}\text { Total root area } \\
\left(\mu \mathrm{m}^{2}\right)\end{array}$ & $\begin{array}{c}\text { Vascular } \\
\text { cylinder area } \\
\left(\mu \mathrm{m}^{2}\right)\end{array}$ & $\begin{array}{c}\text { Root diameter } \\
(\mu \mathrm{m})\end{array}$ & $\begin{array}{c}\text { Protoxylem } \\
\text { thickness }(\mu \mathrm{m})\end{array}$ & $\begin{array}{c}\text { Metaxylem } \\
\text { thickness } \\
(\mu \mathrm{m})\end{array}$ \\
\hline BD 686 & $72450.35 \mathrm{~b}$ & $21511.46 \mathrm{a}$ & $264.00 \mathrm{c}$ & $3.87 \mathrm{e}$ & $2.71 \mathrm{e}$ \\
BD 687 & $46451.60 \mathrm{e}$ & $12244.07 \mathrm{~d}$ & $171.70 \mathrm{f}$ & $6.32 \mathrm{~b}$ & $4.23 \mathrm{~b}$ \\
BD 693 & $68950.60 \mathrm{c}$ & $17778.33 \mathrm{~b}$ & $275.90 \mathrm{~b}$ & $4.32 \mathrm{~d}$ & $3.01 \mathrm{~d}$ \\
BD 747 & $43451.75 \mathrm{f}$ & $11698.80 \mathrm{~d}$ & $209.70 \mathrm{e}$ & $5.87 \mathrm{c}$ & $3.93 \mathrm{c}$ \\
BD 750 & $85049.40 \mathrm{a}$ & $18432.04 \mathrm{~b}$ & $319.88 \mathrm{a}$ & $1.98 \mathrm{f}$ & $1.78 \mathrm{f}$ \\
BD 753 & $57451.45 \mathrm{~d}$ & $14926.17 \mathrm{c}$ & $221.55 \mathrm{~d}$ & $7.82 \mathrm{a}$ & $5.07 \mathrm{a}$ \\
\hline LSD & 0.012 & 779.50 & 11.916 & 1.192 & 1.053 \\
\hline
\end{tabular}

In a column figures having similar letter(s) do not differ significantly at $5 \%$ level of probability.

Table 11. Effects of salinity level on anatomical characteristics at vegetative stage

\begin{tabular}{cccccc}
\hline $\begin{array}{c}\text { Salinity } \\
\text { level }\end{array}$ & $\begin{array}{c}\text { Total root } \\
\text { area }\left(\mu \mathrm{m}^{2}\right)\end{array}$ & $\begin{array}{c}\text { Vascular cylinder } \\
\text { area }\left(\mu \mathrm{m}^{2}\right)\end{array}$ & $\begin{array}{c}\text { Root diameter } \\
(\mu \mathrm{m})\end{array}$ & $\begin{array}{c}\text { Protoxylem } \\
\text { thickness }(\mu \mathrm{m})\end{array}$ & $\begin{array}{c}\text { Metaxylem } \\
\text { thickness }(\mu \mathrm{m})\end{array}$ \\
\hline $0 \mathrm{mM}$ & $68300.82 \mathrm{a}$ & $17573.42 \mathrm{a}$ & $265.01 \mathrm{a}$ & $3.62 \mathrm{~b}$ & $2.35 \mathrm{~b}$ \\
$100 \mathrm{mM}$ & $56300.90 \mathrm{~b}$ & $14623.53 \mathrm{~b}$ & $222.57 \mathrm{~b}$ & $6.44 \mathrm{a}$ & $4.56 \mathrm{a}$ \\
\hline LSD & 0.007 & 450.10 & 6.880 & 0.688 & 0.608 \\
\hline
\end{tabular}

In a column figures having similar letter(s) do not differ significantly at $5 \%$ level of probability. 
61
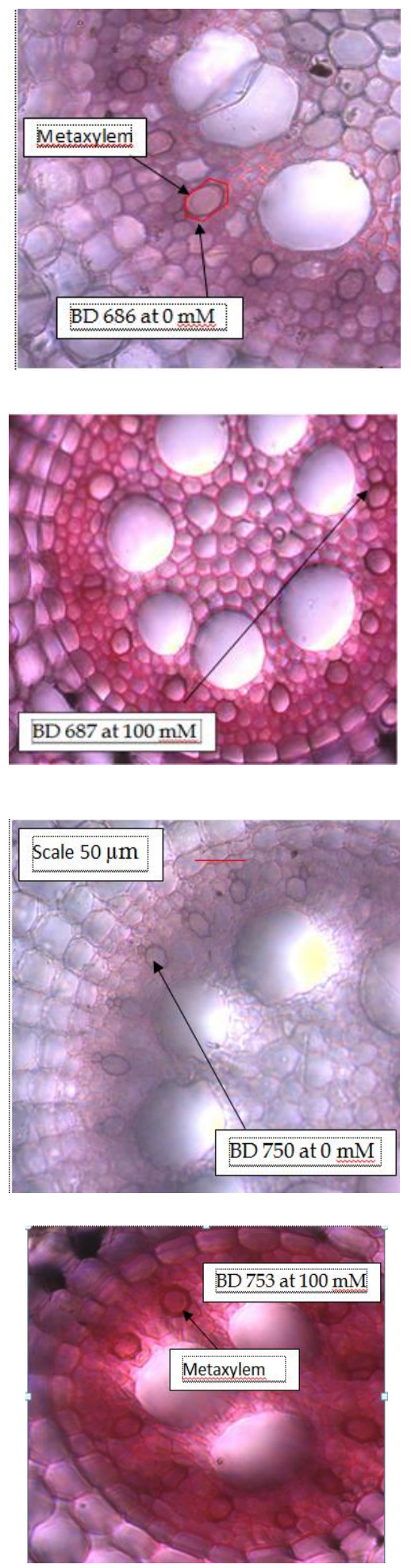

Physiology \& anatomy of sorghum at salinity
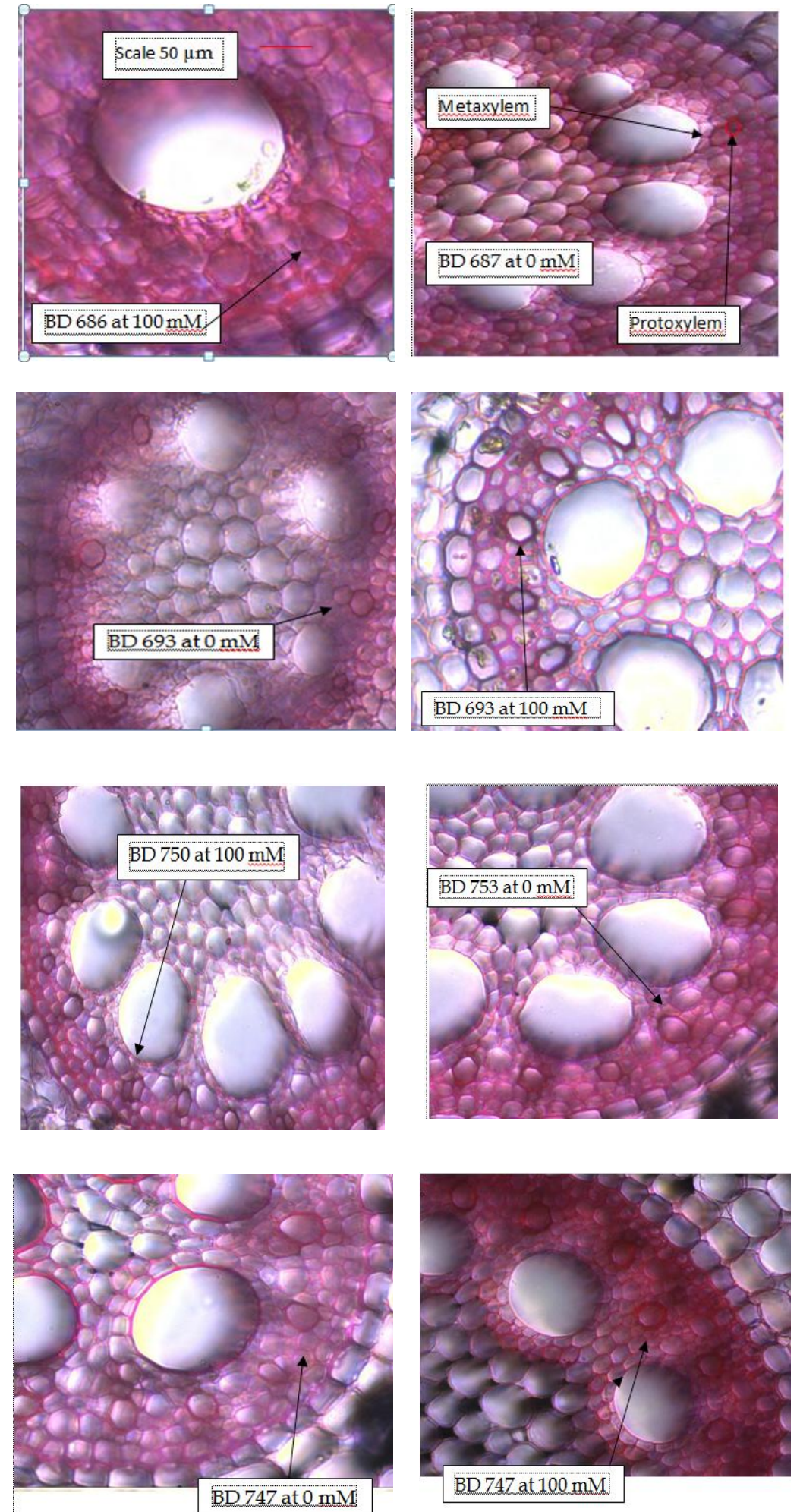

Figure 1. Anatomy of root cross section showing the protoxylem and metaxylem thickness at 0 and $100 \mathrm{mM}$ salinity condition of sorghum 
Table 12. Combined effects of genotypes and salinity level on Anatomical characteristics at vegetative stage

\begin{tabular}{lccccc}
\hline $\begin{array}{l}\text { Interaction of } \\
\text { genotype to } \\
\text { salinity }\end{array}$ & $\begin{array}{c}\text { Total root area } \\
\left(\mu \mathrm{m}^{2}\right)\end{array}$ & $\begin{array}{c}\text { Vascular } \\
\text { cylinder area } \\
\left(\mu \mathrm{m}^{2}\right)\end{array}$ & $\begin{array}{c}\text { Root } \\
\text { diameter } \\
(\mu \mathrm{m})\end{array}$ & $\begin{array}{c}\text { Protoxylem } \\
\text { thickness } \\
(\mu \mathrm{m})\end{array}$ & $\begin{array}{c}\text { Metaxylem } \\
\text { thickness } \\
(\mu \mathrm{m})\end{array}$ \\
\hline T1V1 & $77450.40 \mathrm{c}$ & $22132.29 \mathrm{a}$ & $282.40 \mathrm{~b}$ & $2.82 \mathrm{ef}$ & 1.85 \\
T1V2 & $54451.60 \mathrm{~g}$ & $14201.80 \mathrm{e}$ & $202.80 \mathrm{e}$ & $4.42 \mathrm{cde}$ & 2.85 \\
T1V3 & $74450.50 \mathrm{~d}$ & $19132.70 \mathrm{c}$ & $292.30 \mathrm{~b}$ & $3.12 \mathrm{def}$ & 2.05 \\
T1V4 & $51451.80 \mathrm{~h}$ & $13708.70 \mathrm{e}$ & $237.80 \mathrm{~d}$ & $4.12 \mathrm{cde}$ & 2.65 \\
T1V5 & $87549.30 \mathrm{a}$ & $19632.42 \mathrm{c}$ & $327.25 \mathrm{a}$ & $1.83 \mathrm{f}$ & 1.25 \\
T1V6 & $64451.30 \mathrm{f}$ & $16632.63 \mathrm{~d}$ & $247.50 \mathrm{~cd}$ & $5.43 \mathrm{c}$ & 3.45 \\
T2V1 & $67450.30 \mathrm{e}$ & $20890.63 \mathrm{~b}$ & $245.60 \mathrm{~cd}$ & $4.92 \mathrm{~cd}$ & 3.56 \\
T2V2 & $38451.60 \mathrm{i}$ & $10286.33 \mathrm{f}$ & $140.60 \mathrm{~g}$ & $8.22 \mathrm{~b}$ & 5.61 \\
T2V3 & $63450.70 \mathrm{f}$ & $16423.97 \mathrm{~d}$ & $259.50 \mathrm{c}$ & $5.52 \mathrm{c}$ & 3.96 \\
T2V4 & $35451.70 \mathrm{j}$ & $9688.90 \mathrm{f}$ & $181.60 \mathrm{f}$ & $7.62 \mathrm{~b}$ & 5.21 \\
T2V5 & $82549.50 \mathrm{~b}$ & $17231.67 \mathrm{~d}$ & $312.50 \mathrm{a}$ & $2.12 \mathrm{f}$ & 2.31 \\
T2V6 & $50451.60 \mathrm{~h}$ & $13219.70 \mathrm{e}$ & $195.60 \mathrm{ef}$ & $10.21 \mathrm{a}$ & 6.68 \\
\hline LSD & 0.017 & 1102.00 & 16.852 & 1.685 & 1.489 \\
\hline
\end{tabular}

In a column figures having similar letter(s) do not differ significantly at $5 \%$ level of probability. $\mathrm{V}_{1}=$ BD 686; $\mathrm{V}_{2}=\mathrm{BD} 687 ; \mathrm{V}_{3}=\mathrm{BD} 693 ; \mathrm{V}_{4}=\mathrm{BD} 747 ; \mathrm{V}_{5}=\mathrm{BD} 750 ; \mathrm{V}_{6}=\mathrm{BD} 753 . \mathrm{T}_{1}=0 \mathrm{mM}$ (control); $\mathrm{T}_{2}=100 \mathrm{mM} \mathrm{NaCl}$.

The interaction between salinity levels and genotypes had a significant effect on leaf proline (Table 9). Results revealed that proline content was higher in $\mathrm{T}_{2} \mathrm{~V}_{5}(5.70 \mathrm{mg} / 100 \mathrm{~g} \mathrm{FW})$. In contrast, leaf proline was the lowest in $\mathrm{T}_{1} \mathrm{~V}_{3}$ $(0.80 \mathrm{mg} / 100 \mathrm{~g} \mathrm{FW})$ followed by $\mathrm{T}_{1} \mathrm{~V}_{1}(1.05$ $\mathrm{mg} / 100 \mathrm{~g}$ FW); $\mathrm{T}_{1} \mathrm{~V}_{5}(1.23 \mathrm{mg} / 100 \mathrm{~g}$ FW). A similar trend was endorsed by Munns and Tester (2008) and Flower (2004). This increment of proline concentration was occurred by plants might be due to maintaining osmotic pressure in the cell (Munns and Tester, 2008). Thus, plants use proline as an osmolyte.

\subsection{Effects of salinity on anatomical characteristics}

\subsubsection{Total root area}

The variation in total root area among the studied genotypes was statistically significant (Table 10). Result revealed that the highest total root area was recorded in BD $750\left(85049.40 \mu \mathrm{m}^{2}\right)$. In contrast, BD 747 had the lowest total root area $\left(43451.75 \mu \mathrm{m}^{2}\right)$.
The effect of salinity on total root area was found statistically significant (Table 11). Result revealed that the total root area was decreased with increasing salinity levels. The highest total root area was recorded in control $\left(68300.82 \mu \mathrm{m}^{2}\right)$ and the lowest was recorded in $100 \mathrm{mM}$ salinity level $\left(56300.90 \mu \mathrm{m}^{2}\right)$.

The interaction between salinity levels and genotypes at vegetative stage had a significant effect on total root area. Salinity stress significantly reduced total root area of the sorghum genotypes. Generally, in control condition, total root area was found the highest and it decreased in saline condition. Result revealed that the highest total root area was recorded in $\mathrm{T}_{1} \mathrm{~V}_{5}\left(87549.30 \mu \mathrm{m}^{2}\right)$ while the lowest total root area was observed in $\mathrm{T}_{2} \mathrm{~V}_{4}$ (35451.70 $\mu^{2}$ ) (Table 12).

\subsubsection{Vascular cylinder area (VCA)}

The highest vascular cylinder area was recorded in BD $686\left(21511.46 \mu \mathrm{m}^{2}\right)$. In contrast, BD 747 
had the lowest vascular cylinder area (11698.80 $\mu \mathrm{m}^{2}$ ) (Table 10). The vascular cylinder area was decreased with increasing salinity levels. The highest vascular cylinder area was recorded in control $\left(17573.42 \mu^{2}\right)$ and the lowest was recorded in $100 \mathrm{mM}$ salinity $\left(14623.53 \mu \mathrm{m}^{2}\right)$ (Table 11). Salinity stress significantly reduced vascular cylinder area of the sorghum genotypes. Generally, in control condition, vascular cylinder area was found the highest and it decreased in saline condition. Result revealed that the highest vascular cylinder area was recorded in $\mathrm{T}_{1} \mathrm{~V}_{1}\left(22132.29 \mu \mathrm{m}^{2}\right)$ while the lowest vascular cylinder area was observed in $\mathrm{T}_{2} \mathrm{~V}_{4}(9688.90$ $\mu \mathrm{m}^{2}$ ) (Table 12).

\subsubsection{Root diameter}

The highest root diameter was recorded in $\mathrm{BD}$ $750(319.88 \mu \mathrm{m})$. In contrast, BD 687 had the lowest root diameter $(171.70 \mu \mathrm{m})$ (Table 10). The root diameter was decreased with addition of salt. The highest root diameter was recorded in control $(265.01 \mu \mathrm{m})$ and the lowest was recorded in $100 \mathrm{mM}$ salinity level $(222.57 \mu \mathrm{m})$ (Table 11).Salinity stress significantly reduced root diameter of the sorghum genotypes. Generally, in control condition, root diameter was found the highest and it decreased in saline condition. The highest root diameter was recorded in $\mathrm{T}_{1} \mathrm{~V}_{5}(327.25 \mu \mathrm{m})$ while the lowest vascular cylinder area was observed in $\mathrm{T}_{2} \mathrm{~V}_{2}(140.60 \mu \mathrm{m})$ (Table 12).

\subsubsection{Protoxylem thickness (PX)}

The highest protoxylem thickness was recorded in BD $753(7.82 \mu \mathrm{m})$. In contrast, BD $750 \mathrm{had}$ the lowest protoxylem thickness $(1.98 \mu \mathrm{m})$ (Table 10).The protoxylem thickness was increased with addition of salt, it is due to subirization of cell wall. The highest protoxylem thickness was recorded in $100 \mathrm{mM}$ salinity level $(6.44 \mu \mathrm{m})$ and the lowest was recorded in control condition $(3.62 \mu \mathrm{m})$ (Table 11).Salinity stress significantly increased protoxylem thickness of the sorghum genotypes. Result revealed that the highest thickness was recorded in $\mathrm{T}_{2} \mathrm{~V}_{6}(10.21$ $\mu \mathrm{m})$ while the lowest protoxylem thickness was observed in $\mathrm{T}_{1} \mathrm{~V}_{5}(1.83 \mu \mathrm{m})$ (Table-12).
Protoxylem thickness of root cell increases with increasing of salinity level. This increase of root cell wall is due to accumulation of subirin (Figure 1). These results are agreement with Enstone et al., (2002); Naseer et al., (2012); Baum et al., (2000) in sorghum as well as increased thickness of Casparian strip in maize roots (Karaharae et al., 2004) under salt stress.

\subsubsection{Metaxylem thickness (MX)}

The highest metaxylem thickness was recorded in BD $753(5.07 \mu \mathrm{m})$. In contrast, BD 750 had the lowest metaxylem thickness $(1.78 \mu \mathrm{m})$ (Table 10).The metaxylem thickness was increased with addition of salt. The highest metaxylem thickness was recorded in $100 \mathrm{mM}$ salinity level $(4.56 \mu \mathrm{m})$ and the lowest was recorded in control condition $(2.35 \mu \mathrm{m})$. Metaxylem thickness of root cell increases with increasing of salinity level. This increase of root cell wall is due to accumulation of subirin (Figure 1). These results are agreement with Enstone et al., (2002); Naseer et al., (2012); Baum et al., (2000) in sorghum as well as increased thickness of Casparian strip in maize roots (Karaharae et al., 2004) under salt stress (Table 11).

\section{Conclusions}

It could be concluded based on relative value at hydroponic condition, BD 759 and BD 686 can be expressed as tolerant and BD 747 and BD 753 as susceptible genotypes to salt stress. Moreover, further study is needed to evaluate the genotypes in the field condition, especially in the coastal areas in Bangladesh for their adaptability to grow.

\section{References}

Akram M., Ashraf MY., Jamil M., Iqbal RM., Nafees M., Khan MA. 2011. Nitrogen application improves gas exchange characteristics and chlorophyll fluorescence in maize hybrids under salinity conditions. Russian Journal of Plant Physiology. 58:394-401. 
Almodares A., Hadi MR., Ahmadpour H. 2008: Sorghum Stem Yield and Soluble Carbohydrates Under Different Salinity Levels. Afican Journal of Biotechnology.7: 4051-4055.

Baum SF., Tran PN., Silk WK. 2000. Effects of salinity on xylem structure and water use in growing leaves of sorghum. New Phytologist. 46(1):119-127.

Daffalla HM., Hassan MM., Osman MG., Eltayeb AH., Dagash YI., Gani MEA. 2014: Effect of Seed Priming on Early Development of Sorghum (Sorghum bicolor L. Moench) and Striga hermonthica (Del.) Benth. International Scholarly Research Notices. 8: 4-8.

Enstone DE., Peterson CA., Ma F. 2002: Root endodermis and exodermis structure, function, and responses to the environment. Journal of Plant Growth Regulator. 21(4): 335-351.

FAO. 2015. High level expert forum - how to feed the world in 2050. Economic and Social Development Department, Food and Agricultural Organization of the United Nations, Rome.

Farooq M., Hussain M., Wakeel A., Siddique KHM. 2015. Salt stress in maize: effects, resistance mechanisms and management. A review. Agronomy for Sustainable Development. 35: 461-481. doi:10.1007/s13593-015-0287-0.

Flower TJ. 2004: Improving crop salt tolerance for physiological studies of rice. Journal of Experimental Botany.55:307-319.

Genty B., Briantais J., Baker N. 1989. The relationship between the quantum yield of photosynthetic electron transport and quenching of chlorophyll fluorescence. Biochimia et Biophysica Acta, 990:87-92.

Gomez KA., Gomez. AA. 1984. Statistical procedures for Agricultural Research 2nd Edn.John Willy and Sons., New York. 97$111 \mathrm{pp}$.
Hamid M., Ashraf MY., Rehman KU., Arshad M. 2008. Influence of salicylic acid seed priming on growth and some biochemical attributes on wheat growth under saline conditions. Pakistan Journal of Botany. 40: 361-367.

Hossain MA., Azad MAK., Fakir MSA., Mojakkir AM., Tareq MZ. 2008. Physiological significance of accumulated leaf proline in salinity stressed peanut seedlings. Bangladesh Journal of Environmental Science, 15: 169-174.

House LR. 1995: Sorghum; One of the world's great cereals. African Journal of Crop Science. 3:135- 142.

Kafi M., Jafari MHS., Moayedi A. 2013. The Sensitivity of Grain Sorghum (Sorghum bicolor L.) Developmental Stages to Salinity Stress: An Integrated Approach. Journal of Agricultural Science and Technology. 15: 723-736.

Karaharae I., Ikeda A., Kondo T., Uetake Y. 2004. Development of the Casparian strip in primary roots of maize under salt stress. Planta. 219(1):41-47

Munns R., Tester M. 2008. Mechanisms of salinity tolerance. Annual Review of Plant Biology.59: 651-681. doi:10.1146/annrev.arplant.59.032607.0 92911.

Naseer S., Lee Y., Lapierre C., Franke R., Nawrath C., Geldner N. 2012. Casparian strip diffusion barrier in Arabidopsis is made of a lignin polymer without suberin. Proceedings of the National Academy of Science.109(25): 1010110106.

Netondo GW., Onyango JC., Beck E. 2004. Sorghum and salinity: II. Gas exchange and chlorophyll fluorescence of sorghum under salt stress. Crop Science 44(3):806811.

Niu G., Xu W., Rodriguez D., Sun, Y. 2012. Growth and physiological responses of maize and sorghum genotypes to salt 
stress. ISRN Agronomy. 2012:1-12. doi:10.5402/2012/145072.

Pitann B., Kranz T., Mühling KH. 2009. The apoplastic $\mathrm{pH}$ and its significance in adaptation to salinity in maize (Zea mays L.): comparison of fluorescence microscopy and pH-sensitive microelectrodes. Plant Science. 176:497504.

Queiroz HM., Sodek L., Haddad CRB. 2012. Effect of salt on the growth and metabolism of Glycine max. Brazilian Archieves of Biology and Technology. 55:809-817.

Singh RA., Roy NK., Hoque MS. 2001. Changes in growth and metabolic activity in seedlings of lentil (Lens culinaris Medie) genotypes during salt stress. Indian Journal of Plant Physiology. 6: 406-4 10.
Sultana MA. 2008. Uptake and distribution of $\mathrm{Na}^{+}$in salinity tolerance rice plant. $M S$ Thesis. Dept. of Crop Botany, Bangladesh Agricultural University, Mymensingh.

Szalai G., Janda T. 2009. Effect of salt stress on the salicylic acid synthesis in young maize (Zea mays L.) plants. Journal of Agronomy and Crop Science. 195: 165171. doi: $10.1111 /$ j.1439037x.2008.00352.x.

Tareq MZ. 2009. Effect of salinity on reproductive growth of bread wheat. $M S$ thesis. Dept. of Crop Botany, Bangladesh Agricultural University, Mymensingh.

Zhang Z., Huang R. 2013. Analysis of malondialdehyde, chlorophyll proline, soluble sugar, and glutathione content in Arabidopsis seedling. Bio-protocol. https://doi.org/10.21769/BioProtoc.817. 